\title{
California law will prohibit genetic discrimination
}

San Francisco. The governor of California, Pete Wilson, has signed into law a bill prohibiting health insurance companies from discriminating against policy holders or applicants on the basis of asymptomatic genetic characteristics. It also defines the onset of a genetic disease as starting with the appearance of symptoms, not in the demonstration of a genetic susceptibility.

Under the law, which was approved on 23 September, insurers will not have access to the results of genetic tests, and will not be able to use information on genetic status to deny coverage or raise rates to somebody who has no disease symptoms. Violation will result in financial penalties.

The new state law, which also prohibits doctors from releasing genetic test results to insurers or employers, is believed to be the strongest such law in the United States because of the breadth of its definition of genetic information and the number of entities it covered.

Individual and group health insurance, small life insurance policies and group life and disability insurance would be included. Insurers could ask for genetic tests only in the case of large life and disability income policies that already require other types of testing.

Paul Billings, associate clinical professor of medicine at Stanford University and an advocate of genetic privacy protection, claims that privacy and insurance protection were necessary to create an environment in

\section{US urged to apply cancer research}

Washington. A lack of support for "translational research" to carry the results of basic research into the realm of patient care is hampering US efforts in the war against cancer, a panel of leading cancer experts has told Congress.

In a report published in Washington last week, a subpanel of the National Cancer Advisory Board, chaired by Paul Calabresi of Brown University, Rhode Island, calls for an extra $\$ 60$ million a year to be spent on research aimed at improving the links between the latest laboratory findings and patient care.

The money should be spent through 60 existing clinical cancer centres approved by the National Cancer Institute (NCI) across the country, the report says. It claims that translational researchers - for example, those who move basic research into technology development, or conduct early clinical trials of laboratory findings - are "an endangered species" under the existing funding structure, and that young scientists consider entry to the which the full benefits of genetic testing could be realized.

Billings claims that the state took an important step by defining the onset of genetic disease as the start of its symptoms. This could be particularly important as genes are discovered for cancer and heart disease and in late-onset diseases such as Huntington's chorea.

"We are getting so technologically adept at analysing DNA that we don't quite know when illness begins," says Billings. "It's important because people won't have to grow up with the stigma [or] with the great burden of illness their whole lives."

State senator Patrick Johnston, who represents the Sacramento/San Joaquin region and worked for three years as sponsor of the California bill, said he hoped the new law would encourage people to take genetic tests without fear of losing their insurance.

But some are worried that the new law does not go far enough. Joanna Fanos, for example, a research psychologist at the California Pacific Medical Center in San Francisco, says that other forms of protection may be necessary to ensure that the law is implemented appropriately, and that individual are not pressurized into taking tests. Fanos is a member of a social issues subcommittee of the American Society of $\mathrm{Hu}$ man Genetics that is developing guidelines on testing in children and adolescents.

Sally Lehrman

field to be "professional suicide".

The report, which was requested by the Senate and House appropriations subcommittees responsible for funding cancer research, also asks for an extra $\$ \mathbf{\$ 1 8 0}$ million for basic cancer research. Congressional staff reacted coolly to the appeal for extra funds, however, noting that their request for the report two years ago had asked only for an evaluation of the use of existing resources.

The report does call for such a detailed evaluation of the existing \$2-billion cancer research programme, and Harold Varmus, director of the National Institutes of Health, has already approved it.

The panel finds that the considerable progress made by cancer researchers has not always been converted into better care, especially among the poor and the elderly. But it says that talk of health-care reform earlier this year was "devastating the war on cancer by denying resources for research and quality cancer care". Colin Macilwain

\section{Gene advisory group switches focus to ethical issues}

Washington. The Recombinant DNA Advisory Committee (RAC) of the US National Institutes of Health $(\mathrm{NIH})$ is to withdraw from vetting protocols for routine experiments with human gene therapy in order to concentrate on broader ethical issues.

Partly in response to complaints from industry that submitting new protocols for experiments similar to those already approved creates too much extra paperwork, and partly at the urging of $\mathrm{NIH}$ director Harold Varmus the RAC is to hand over responsibility for approving standard protocols to the Food and Drug Administration (FDA).

Leroy Walters, professor of philosophy at Georgetown University in Washington, and chairman of the RAC, told the House of Representatives Committee on Science, Space and Technology last week that in future, only protocols raising novel scientific or ethical questions would be submitted to his committee.

The RAC voted at a meeting last month both to approve this change in its role, and to become an advisory committee to the FDA as well as to the NIH. Varmus had asked the RAC to consider whether it should continue to review all protocols, or spend more of its time looking at broader ethical issues.

Philip Noguchi, director of cellular and group therapies at the FDA, says that industry will initially see little difference between old and new procedures, but that the reduction in RAC's responsibilities is an important step towards meeting industry's concerns.

According to Noguchi, the change will free the RAC to spend more time dealing with the ethical issues that will arise from human gene therapy.

The RAC was created in 1974 to draw up guidelines for the emerging field of recombinant DNA technology. As it developed the guidelines it tended to become involved with genetic engineering as well. "There were always new experiments testing categories," says to Sheldon Krimsky, professor of urban and environmental development at Tufts University, and a member of RAC in the late 1970s. "It was an inductive way of establishing guidelines."

As the field of genetic engineering has developed, the RAC has gone through various changes, recently the Environmental Protection Agency took over the regulation of large-scale field tests of genetically engineered products. "The RAC has been straying from its original purpose, and these changes take it back to its original intent," says Alan Smith, chief scientist at the biotechnology company Genzyme.

The proposed changes are supported by both Varmus and David Kessler, head of the FDA. They are expected to come into effect at the end of the year. Helen Gavaghan 